\title{
Estimation of Heavy Metal Concentrations in the Water of Urban Lakes in the Russian Arctic (Murmansk)
}

\author{
Marina A. Postevaya ${ }^{1,2, *}$, Zakhar I. Slukovskii ${ }^{1}$, Vladimir A. Dauvalter ${ }^{1} \mathbb{C}$ and Daria S. Bernadskaya ${ }^{1}$ \\ 1 Institute of the North Industrial Ecology Problems of Kola Science Center of RAS, 184209 Apatity, Russia; \\ slukovsky87@gmail.com (Z.I.S.); vladimir@dauvalter.com (V.A.D.); d.bernadskaya@ksc.ru (D.S.B.) \\ 2 Department of Natural Sciences, Murmansk Arctic State University, 183038 Murmansk, Russia \\ * Correspondence: Postevaya.ma@yandex.ru; Tel.: +7-908-606-3842
}

check for

updates

Citation: Postevaya, M.A.; Slukovskii, Z.I.; Dauvalter, V.A.; Bernadskaya, D.S. Estimation of Heavy Metal Concentrations in the Water of Urban Lakes in the Russian Arctic (Murmansk). Water 2021, 13, 3267. https://doi.org/10.3390/ w13223267

Academic Editor:

Bahram Gharabaghi

Received: 11 October 2021

Accepted: 15 November 2021

Published: 17 November 2021

Publisher's Note: MDPI stays neutral with regard to jurisdictional claims in published maps and institutional affiliations.

Copyright: (C) 2021 by the authors Licensee MDPI, Basel, Switzerland. This article is an open access article distributed under the terms and conditions of the Creative Commons Attribution (CC BY) license (https:// creativecommons.org/licenses/by/ $4.0 /)$.

\begin{abstract}
This article presents the results of the analysis and estimation of the seasonal variation of heavy metals in the water of urban lakes and the assessment of their environmental state based on the chemical data. The research covered seven lakes in Murmansk, subject to various levels of anthropogenic load. Field studies were conducted in 2019-2020. Water samples were taken both in summer and in winter/spring seasons. The most polluted lake was Lake Ledovoe, where the highest concentrations of $\mathrm{V}, \mathrm{Cr}, \mathrm{Co}, \mathrm{Ni}, \mathrm{Cu}, \mathrm{W}$, and $\mathrm{Mn}$ were found. Lake Yuzhnoe, which is characterized by the lowest concentrations of studied heavy metals, was the least subject to anthropogenic load. In total, $\mathrm{V}, \mathrm{Ni}, \mathrm{Zn}, \mathrm{Fe}$, and Mn were above the background levels in the lakes of Murmansk. The analysis of the seasonal variation showed that the highest concentrations of heavy metals were found in winter/spring season and reached their maximum during the period of melt water intake from the catchment area. The research showed the impact of the urban environment on the chemical composition of the Murmansk lakes.
\end{abstract}

Keywords: small lakes; heavy metals; water pollution; urbanization; Arctic

\section{Introduction}

Among the pollutants, heavy metals pose the highest risk to aquatic ecosystems due to their toxicity, resistance to biodegradation, and high potential for accumulation in organisms [1-3]. Toxic impact of heavy metals on aquatic organisms causes negative effects on the nervous, digestive, and respiratory systems of animals and the photosynthesis of plants [4,5]. This happens because the main targets for heavy metals at the molecular level are proteins and enzymes, involved in various vital functions. Thus, due to excessive input of $\mathrm{Cu}$ and $\mathrm{Ni}$ into the lakes of the north-western part of Murmansk region (operations of Kola Mining-Metallurgical Company) fish suffer from pathological changes in organs and tissues, such as intensive growth of the connective tissue in kidneys, kidney stone disease, pathologies in gonads (segmented gonads, medullary form of gonads), etc. This is explained by the fact that the fish liver is the organ of the greatest accumulation of $\mathrm{Cu}$ («target organ»). At the same time, $\mathrm{Ni}$ is mostly concentrated in the kidneys. The spatial features of the accumulation of these metals, especially $\mathrm{Ni}$, in the «target organs» of Coregonus lavaretus are subject to the gradient dependence relative to the source of contamination (the «Pechenganikel» plant). Thus, the average Ni content in the whitefish kidneys from Lake Kuetsjarvi (2 km from the plant) was $30 \mu \mathrm{g} / \mathrm{g}$ dry weight, and in the forest lake Kocheyaur ( $109 \mathrm{~km}$ from the source of pollution) the $\mathrm{Cu}$ content did not exceed $3 \mu \mathrm{g} / \mathrm{g}$ dry weight. At the same time, the frequency of occurrence of pathological kidney changes in these lakes is 100 and $80 \%$, respectively [6].

Heavy metals are toxic for plankton (especially filter feeders) — these organisms concentrate metals that remain in cells for an unlimited period of time, cause their death, and then accumulate in sediments. The filter type of daphnia nutrition makes them highly sensitive to the presence of toxic substances in the aquatic environment. $\mathrm{Cu}$ ions exhibit 
acute toxicity in Daphnia magna at concentrations of 0.1 and $1 \mu \mathrm{g} / \mathrm{L}, \mathrm{Zn}, \mathrm{Co}$, and $\mathrm{Ni}$ ions at the same concentrations exhibit chronic toxicity [7].

Heavy metals inputs to water bodies occur due to both natural processes and anthropogenic impact. The main natural sources of heavy metals in water bodies are rock weathering, wind transportation, release from sediments, and mineralization of organic matter in the catchment area and the water body itself [8-11]. Anthropogenic sources are various industries (metallurgical, mining, chemical, engineering, thermal power), housing and public utilities, transport, agriculture, etc. [12].

Increased anthropogenic impact on the environment in urbanized areas and industrial centers results in higher rates of heavy metals and other pollutants in the surface water. Studies in Wuhan, China showed the tendency towards increased concentrations of heavy metals and other elements $(\mathrm{Cd}, \mathrm{Co}, \mathrm{Pb}, \mathrm{Ni}, \mathrm{Cu}, \mathrm{Zn}, \mathrm{Mn}, \mathrm{Fe}, \mathrm{Al})$ in urban lakes water compared to water bodies in rural areas. For example, in the waters of the urban lakes, the concentration of Co was $3.3 \mu \mathrm{g} / \mathrm{L}, \mathrm{Pb} 10.04 \mu \mathrm{g} / \mathrm{L}$, As $45.19 \mu \mathrm{g} / \mathrm{L}, \mathrm{Al} 5.59 \mu \mathrm{g} / \mathrm{L}$, Ni $18.22 \mu \mathrm{g} / \mathrm{L}, \mathrm{Mn} 656.24 \mu \mathrm{g} / \mathrm{L}$, which exceeded the values recorded for rural lakes by 9, 7, 14, 15.5, 3, and 15 times, respectively [13]. Mining operations in the Tri-State Mining District (TSMD) of southwest Missouri, northeast Oklahoma, and southeast Kansas (the USA) caused long-term input of $\mathrm{Cd}, \mathrm{Pb}$, and $\mathrm{Zn}$ to the environment. Even though mining operations were shut down totally in 1970, there is still an abundance of $\mathrm{Cd}, \mathrm{Pb}$, and $\mathrm{Zn}$ in floodplain soils and sediments of rivers and streams. The highest concentrations of $\mathrm{Pb}$ and $\mathrm{Zn}$ are closely related to the geographical location of the former mining and smelting centers. Thus, the content of $\mathrm{Pb}$ and $\mathrm{Zn}$ in flood-plain soils and Tar Creek sediments in Kansas was 409 and $37 \mathrm{mg} / \mathrm{kg}$, respectively. In Oklahoma, the Pb level was $200 \mathrm{mg} / \mathrm{kg}$, Zn was $2000 \mathrm{mg} / \mathrm{kg}$. The state of Missouri was characterized by the lowest concentrations compared to other states, however, metal concentrations were at a high level $(\mathrm{Pb}-145 \mathrm{mg} / \mathrm{kg}$; $\mathrm{Zn}-1755 \mathrm{mg} / \mathrm{kg}$ ) [14]. In the water bodies near the city of Lulea in northern Sweden, there was an excess of concentrations of heavy metals in the waters and sediments. This is explained by the inflow of stormwater from urban areas and point sources of pollution. Stormwater was characterized by a high content of Cd $0.2 \mu \mathrm{g} / \mathrm{L}, \mathrm{Cu} 22 \mu \mathrm{g} / \mathrm{L}, \mathrm{Pb} 70 \mu \mathrm{g} / \mathrm{L}$, $\mathrm{Zn} 82 \mu \mathrm{g} / \mathrm{L}$. At the same time, the existing redox conditions in water bodies mainly cause the fixation of pollutants in precipitation due to the formation of sulfides and slow oxidation of organic pollutants [15]. According to the long-term studies in the north of Russia, the greatest contribution to the transformation of the chemical composition of water and sediments of Lake Imandra, on which several cities of Murmansk region are located, was made by mining, extraction, processing, and metallurgical industries. Concentrations of heavy metals $(\mathrm{Ni}, \mathrm{Cu}, \mathrm{Co}, \mathrm{Zn}, \mathrm{Cd}, \mathrm{Pb}, \mathrm{As}, \mathrm{Hg}, \mathrm{Cr})$ in the surface layers of sediments have increased by dozens, hundreds, and thousands of times (e.g., Ni) above the background as a result of anthropogenic influence on the lake. Thus, in the surface layers of sediments of the Monche Bay (Bolshaya Imandra), there were significant increases in concentrations of heavy metals compared to the deep background layer. The Ni concentration increased from 50 to $30,000 \mathrm{mg} / \mathrm{g}$, while the copper content changed from 50 to $6000 \mu \mathrm{g} / \mathrm{g}$.

The increase in the content by more than an order of magnitude was also recorded for other heavy metals- $\mathrm{Co}, \mathrm{Zn}, \mathrm{Cd}, \mathrm{Pb}, \mathrm{As}, \mathrm{Hg}, \mathrm{Cr}$, which are the accompanying metals in copper-nickel ore $[16,17]$. Thus, the problem of surface water pollution with heavy metals in urbanized areas is significant, especially regarding the fact that urban rivers and lakes can be used for recreational, cultural, and social purposes by the local population. Therefore, this problem extends beyond the issue of fundamental science, affecting social, economic, and even political aspects of people's lives. The objective of this study is to estimate the seasonal variation of heavy metals in the surface waters of Murmansk, the largest city north of the Arctic Circle, and the environmental state of lakes based on the chemical data.

\section{Materials and Methods}

The article presents the results of the field studies of Murmansk in 2019-2020. The research covered seven lakes in the city of Murmansk (Semenovskoe, Ledovoe, Severnoe, 
Okunevoe, Srednee, Yuzhnoe, Treugolnoe) subject to various levels of anthropogenic load from the main sources of pollution (heating plants, the coal terminal, the waste incineration plant, etc.). It is noteworthy that three selected lakes are not officially named and two of them were named according to their geographical location: (Severnoe (Northern) and Yuzhnoe (Southern)), Lake Treugolnoe (Triangular) was named by the authors because of its shape (Figure 1).

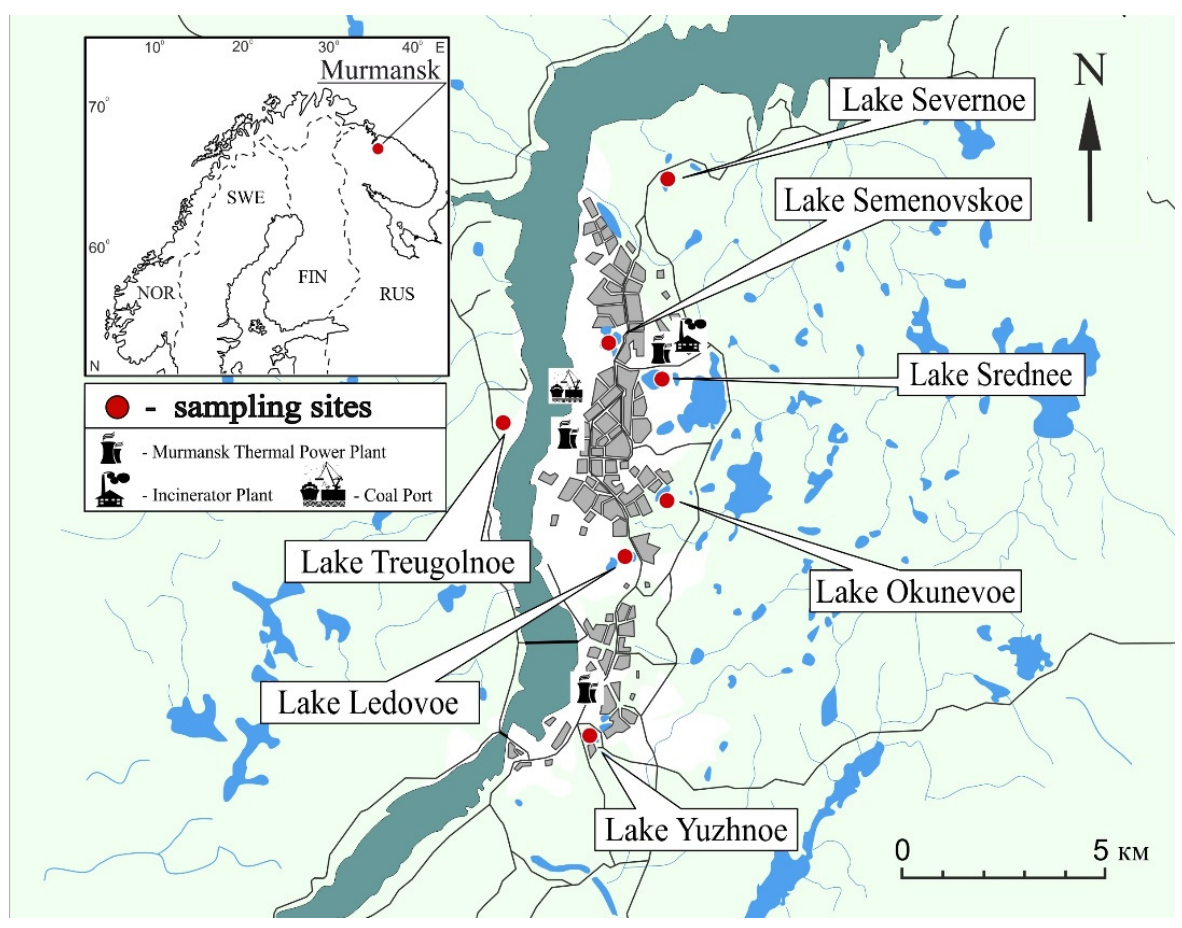

Figure 1. Schematic map of the location of research objects.

The largest lakes are Srednee and Semenovskoe, the deepest ones are also Srednee and Ledovoe with maximum depths 23.5 and $15.7 \mathrm{~m}$ respectively (Table 1). According to the classification of Alekin [18], the waters in the studied lakes mainly belong to the chloride class, Na group, owing to the influence of marine aerosols from Kola Bay [19]. The exceptions are Lake Okunevoe and Lake Srednee as their water is typical for the majority of lakes in Murmansk region, characterized by the distribution patterns of main ions in the bicarbonate $\left(\mathrm{HCO}_{3}{ }^{-}\right)$class, Ca group. These lakes are characterized by low mineralization (mean $63-143 \mathrm{mg} / \mathrm{L}$ ), the highest rates of mineralization are observed in Lake Yuzhnoe and Lake Ledovoe (294 and $612 \mathrm{mg} / \mathrm{L}$, respectively) [20].

Water samples from the surface ( $1 \mathrm{~m}$ from the surface) water and the bottom $(1 \mathrm{~m}$ from the bottom) water of the lakes were taken with a $2 \mathrm{~L}$ plastic bathometer. From the bathometer, the samples were poured into $1 \mathrm{~L}$ plastic bottles from Nalgene ${ }^{\circledR}$, the material of which does not have sorbing properties. Before use, the bottles were thoroughly washed in the laboratory. When sampling water, the bottles were rinsed twice with lake water, then placed in dark containers and refrigerated $\left(\sim+4{ }^{\circ} \mathrm{C}\right)$, and in a short time transported to the laboratory. Filtration of water samples was carried out in the laboratory during discharge using a Millipore phase sepa ration unit from high-density polypropylene through glass and polycarbonate membrane filters of Millipore with a pore size of $0.45 \mu \mathrm{m}$. The following parameters were determined in taken samples: $\mathrm{pH}$, conductivity, alkalinity, main ions $\left(\mathrm{Ca}, \mathrm{Mg}, \mathrm{Na}, \mathrm{K}, \mathrm{HCO}_{3}, \mathrm{SO}_{4}, \mathrm{Cl}\right)$, and mineralization as the sum of seven main ions. The quality of chemical-analytical measurements carried out in the laboratory was confirmed by participation in the annual international verification (Intercomparison 2019). The content of trace elements $(\mathrm{V}, \mathrm{Cu}, \mathrm{Ni}, \mathrm{Cr}, \mathrm{Zn}, \mathrm{Cd}, \mathrm{Sb}, \mathrm{Sn}, \mathrm{Pb})$ in water samples was measured using an ELAN 9000 inductively coupled plasma mass spectrometer. 
Table 1. The main morphometric characteristics and geographic coordinates of the Murmansk lakes.

\begin{tabular}{|c|c|c|c|c|c|c|}
\hline \multirow{2}{*}{ Lakes } & \multirow{2}{*}{$\begin{array}{l}\text { Geographic } \\
\text { Coordinates }\end{array}$} & \multirow{2}{*}{ Area, $\mathbf{k m}^{2}$} & \multirow{2}{*}{$\begin{array}{l}\text { Perimeter of } \\
\text { the Lake, } m\end{array}$} & \multirow{2}{*}{$\begin{array}{l}\text { Maximum Length } \\
\text { of the Lake, m }\end{array}$} & \multicolumn{2}{|c|}{ Depth, m } \\
\hline & & & & & Max. & Mean \\
\hline Severnoe & $\begin{array}{l}69.032664^{\circ} \mathrm{N} \text { and } \\
33.117487^{\circ} \mathrm{E}\end{array}$ & 0.009 & 520 & 230 & 3.90 & 1.75 \\
\hline Ledovoe & $\begin{array}{c}68.93313^{\circ} \mathrm{N} \text { and } \\
33.10451^{\circ} \mathrm{E}\end{array}$ & 0.040 & 780 & 270 & 15.70 & 7.80 \\
\hline Okunevoe & $\begin{array}{c}68.95012^{\circ} \mathrm{N} \text { and } \\
33.12734^{\circ} \mathrm{E}\end{array}$ & 0.048 & 1270 & 550 & 5.60 & 2.30 \\
\hline Semenovskoe & $\begin{array}{c}68.99080^{\circ} \mathrm{N} \text { and } \\
33.08851^{\circ} \mathrm{E}\end{array}$ & 0.213 & 3200 & 730 & 11.30 & 2.40 \\
\hline Srednee & $\begin{array}{c}68.98147^{\circ} \mathrm{N} \text { and } \\
33.12422^{\circ} \mathrm{E}\end{array}$ & 0.248 & 1990 & 700 & 23.50 & 7.70 \\
\hline Yuzhnoe & $\begin{array}{c}68.88469^{\circ} \mathrm{N} \text { and } \\
33.07660^{\circ} \mathrm{E}\end{array}$ & 0.053 & 1130 & 430 & 11.30 & 3.05 \\
\hline Treugolnoe & $\begin{array}{l}68.967875^{\circ} \mathrm{N} \text { and } \\
33.002587^{\circ} \mathrm{E}\end{array}$ & 0.100 & 550 & 160 & 8.60 & 5.60 \\
\hline
\end{tabular}

Lake Semenovskoe was chosen to study the seasonal variation of heavy metals because this lake is the most popular water body among locals and visitors of Murmansk. Chemical and analytical studies were conducted in Institute of North Industrial Ecology Problems and Institute of Geology, KRCRAS using the same methods [21].

\section{Results}

According to the data analysis, concentrations of $\mathrm{Mo}, \mathrm{Cd}, \mathrm{Sn}, \mathrm{Sb}, \mathrm{TI}, \mathrm{Pb}$, and $\mathrm{Bi}$ in the studied water bodies did not exceed the regional relative background [22] and the maximum permissible concentrations for fisheries [23] (Table 2).

\subsection{Water Chemistry}

Vanadium concentrations in the lakes varied from 0.95 to $9.1 \mu \mathrm{g} / \mathrm{L}$. The highest $\mathrm{V}$ rates were found in Lake Ledovoe $(9.1 \mu \mathrm{g} / \mathrm{L})$, Lake Srednee $(8.3 \mu \mathrm{g} / \mathrm{L})$, and Lake Okunevoe $(5.8 \mu \mathrm{g} / \mathrm{L})$. Operations of thermal power plants, using mazut (the Murmansk thermal power plant and boiler rooms) significantly influence the increase of the element rates in urban lakes. It is known that mazut contains vanadium and such heat and power plants can pollute urban areas around the world [24,25]. The concentrations of $\mathrm{V}$ in lakes decreased with distance to the sources of emissions, however, concentrations 3-4 times above the background were found even in the remote lakes (Severnoe, Treugolnoe). This happens mostly because transport distance of ash particles from heat and power plants using mazut can reach $15 \mathrm{~km}$ from the source [26].

Nickel is the main siderophile element of the Baltic Shield [27] and its background is $1.06 \mu \mathrm{g} / \mathrm{L}$. Ni concentrations in the studied lakes varied from 2.8 to $11.74 \mu \mathrm{g} / \mathrm{L}$, which are 2.6-11 times higher than the regional background. Meanwhile, it was found that Lake Ledovoe was characterized by the highest concentration of this element $(11.73 \mu \mathrm{g} / \mathrm{L})$. The lowest Ni content, as well as V, was observed in Lake Yuzhnoe. This element as well as vanadium is an indicator of the combustion of mazut fuel [28-30]. The defined mean positive correlation (Figure 2) between $\mathrm{V}$ and $\mathrm{Ni}$ concentrations (critical value $\mathrm{r}=0.54$ with significance level $p=0.005$ ) in the studied lakes confirmed the significant anthropogenic influence of the Murmansk combine heat and power plant and boiler rooms on the state of water bodies. 
Table 2. The mean concentrations of microelements in the Murmansk lakes, $\mu \mathrm{g} / \mathrm{L}$.

\begin{tabular}{|c|c|c|c|c|c|c|c|c|c|}
\hline Elements & Semenovskoe & Ledovoe & Severnoe & Okunevoe & Srednee & Yuzhnoe & Treugolnoe & $\begin{array}{c}\text { Background } \\
{[22]}\end{array}$ & $\begin{array}{c}\text { MPC } \\
\text { Fish [23] }\end{array}$ \\
\hline$n$ & 9 & 4 & 3 & 3 & 4 & 3 & 2 & & \\
\hline $\mathrm{V}$ & $\frac{2.8 \pm 1.85}{1.9(0.96-6.4)}$ & $\frac{9.1 \pm 5}{10.1(2-13)}$ & $\frac{2.9 \pm 0.7}{2.9(2.1-3.6)}$ & $\frac{5.8 \pm 4.6}{3.2(2.9-11.1)}$ & $\frac{8.3 \pm 12.4}{2.4(1.5-26.9)}$ & $\frac{0.9 \pm 0.3}{0.8(0.8-1.3)}$ & $\frac{2.4 \pm 1.2}{2.4(1.5-3.2)}$ & 0.67 & 1 \\
\hline $\mathrm{Cr}$ & $\frac{0.4 \pm 0.08}{0.4(0.3-0.6)}$ & $\frac{1.6 \pm 0.56}{1.7(0.9-2.2)}$ & $\frac{0.7 \pm 0.03}{0.7(0.6-0.7)}$ & $\frac{0.95 \pm 0.06}{1(0.9-1)}$ & $\frac{0.6 \pm 0.05}{0.5(0.5-0.6)}$ & $\frac{0.7 \pm 0.2}{0.7(0.5-0.8)}$ & $\frac{0.8 \pm 0.05}{(0.7-0.8)}$ & 0.50 & 70 \\
\hline Co & $\frac{0.17 \pm 0.24}{0.06(0.04-0.8)}$ & $\frac{1.39 \pm 0.53}{1.2(1-2.2)}$ & $\frac{0.52 \pm 0.42}{0.3(0.27-1)}$ & $\frac{0.14 \pm 0.02}{0.15(0.12-0.16)}$ & $\frac{0.11 \pm 0.05}{0.08(0.07-0.19)}$ & $\frac{0.1 \pm 0.003}{0.1(0.1-0.11)}$ & $\frac{0.6 \pm 0.8}{0.6(0.07-1.19)}$ & 0.47 & 10 \\
\hline $\mathrm{Ni}$ & $\frac{4.13 \pm 0.8}{4.2(3.25 .4)}$ & $\frac{11.74 \pm 5.2}{10.7(7.2-18.4)}$ & $\frac{5.5 \pm 1.1}{5.6(4.4-6.6)}$ & $\frac{5.9 \pm 1.6}{5.1(4.9-7.8)}$ & $\frac{6.8 \pm 3.6}{5.2(4.5-12.2)}$ & $\frac{2.8 \pm 0.6}{2.9(2.1-3.3)}$ & $\frac{7.1 \pm 6.9}{7(2.2-12)}$ & 1.06 & 10 \\
\hline $\mathrm{Cu}$ & $\frac{1.7 \pm 0.3}{1.7(1.22)}$ & $\frac{2.6 \pm 1.4}{2.4(1.2-4.4)}$ & $\frac{2.3 \pm 0.8}{2.1(1.5-3.1)}$ & $\frac{2.5 \pm 0.5}{2.3(2.2-3)}$ & $\frac{2 \pm 0.8}{1.8(1.4-3.2)}$ & $\frac{1.3 \pm 0.2}{1.4(1.1-1.5)}$ & $\frac{2.5 \pm 0.8}{2.5(1.9-3)}$ & 0.94 & 1 \\
\hline $\mathrm{Zn}$ & $\frac{6.4 \pm 3.9}{5.7(2.615)}$ & $\frac{10.4 \pm 4.6}{8.9(6.7-17.1)}$ & $\frac{14.8 \pm 6}{11.4(11.3-21.7)}$ & $\frac{17.2 \pm 11.1}{11(10.6-30.1)}$ & $\frac{7 \pm 6}{4.7(2.7-15.8)}$ & $\frac{1.6 \pm 0.16}{1.6(1.5-1.8)}$ & $\frac{5.6 \pm 2.3}{5.6(4-7.3)}$ & 1.66 & 10 \\
\hline Mo & $\frac{0.11 \pm 0.02}{0.1(0.090 .16)}$ & $\frac{0.41 \pm 0.14}{0.4(0.26-0.55)}$ & $\frac{0.74 \pm 0.28}{0.7(0.5-1.05)}$ & $\frac{0.14 \pm 0.04}{0.1(0.11-0.19)}$ & $\frac{0.25 \pm 0.08}{0.2(0.19-0.37)}$ & $\frac{0.32 \pm 0.01}{0.3(0.3-0.32)}$ & $\frac{0.02 \pm 0.01}{0.02(0.007-0.03)}$ & 0.55 & 500 \\
\hline $\mathrm{Cd}$ & $\frac{0.01 \pm 0.003}{0.01(0.0080 .02)}$ & $\frac{0.02 \pm 0.004}{0.02(0.01-0.02)}$ & $\frac{0.03 \pm 0.015}{0.03(0.02-0.05)}$ & $\frac{0.03 \pm 0.02}{0.02(0.02-0.06)}$ & $\frac{0.06 \pm 0.05}{0.04(0.018-0.13)}$ & $\frac{0.01 \pm 0.008}{0.01(0.007-0.02)}$ & $\frac{0.02 \pm 0.01}{0.02(0.01-0.02)}$ & 0.36 & 5 \\
\hline Sn & $\frac{0.008 \pm 0.007}{0.008(0.0020 .02)}$ & $\frac{0.059 \pm 0.029}{0.057(0.027-0.096)}$ & $\frac{0.029 \pm 0.04}{0.009(0.003-0.076)}$ & $\frac{0.036 \pm 0.001}{0.037(0.035-0.038)}$ & $\frac{0.028 \pm 0.026}{0.025(0.001-0.06)}$ & $\frac{0.005 \pm 0.005}{0.002(0.002-0.01)}$ & $\frac{0.025 \pm 0.015}{0.025(0.014-0.036)}$ & 0.50 & 112 \\
\hline $\mathrm{W}$ & $\frac{0.009 \pm 0.006}{0.007(0.005-0.03)}$ & $\frac{1.39 \pm 0.62}{1.62(0.51-1.84)}$ & $\frac{0.07 \pm 0.03}{0.06(0.05-0.10)}$ & $\frac{0.02 \pm 0.009}{0.03(0.01-0.03)}$ & $\frac{0.01 \pm 0.008}{0.01(0.004-0.02)}$ & $\frac{0.02 \pm 0.005}{0.02(0.016-0.025)}$ & $\frac{0.006 \pm 0.002}{0.006(0.004-0.007)}$ & 0.61 & 0.8 \\
\hline $\mathrm{Tl}$ & $\frac{0.004 \pm 0.001}{0.004(0.003-0.007)}$ & $\frac{0.007 \pm 0.004}{0.008(0.003-0.011)}$ & $\frac{0.009 \pm 0.003}{0.007(0.007-0.012)}$ & $\frac{0.005 \pm 0.002}{0.004(0.003-0.007)}$ & $\frac{0.003 \pm 0.001}{0.003(0.002-0.005)}$ & $\frac{0.002 \pm 0.001}{0.001(0.001-0.003)}$ & $\frac{0.004 \pm 0.00007}{0.004(0.0035-0.0036)}$ & 1.85 & 60 \\
\hline $\mathrm{Pb}$ & $\frac{0.14 \pm 0.08}{0.13(0.07-0.3)}$ & $\frac{0.27 \pm 0.06}{0.3(0.22-0.4)}$ & $\frac{0.2 \pm 0.03}{0.2(0.17-0.22)}$ & $\frac{0.45 \pm 0.08}{0.4(0.39-0.54)}$ & $\frac{0.12 \pm 0.10}{0.1(0.03-0.26)}$ & $\frac{0.07 \pm 0.01}{0.07(0.06-0.08)}$ & $\frac{0.37 \pm 0.22}{0.37(0.21-0.53)}$ & 0.47 & 6 \\
\hline $\mathrm{Bi}$ & $\frac{0.004 \pm 0.006}{0.0007(0.0002-0.02)}$ & $\frac{0.014 \pm 0.004}{0.016(0.007-0.02)}$ & $\frac{0.007 \pm 0.004}{0.009(0.002-0.009)}$ & $\frac{0.004 \pm 0.004}{0.003(0.0003-0.008)}$ & $\frac{0.007 \pm 0.001}{0.007(0.005-0.007)}$ & $\frac{0.004 \pm 0.003}{0.004(0.001-0.006)}$ & $\frac{0.01 \pm 0.002}{0.01(0.007-0.011)}$ & 1.06 & - \\
\hline $\mathrm{Mn}$ & $\frac{77 \pm 134}{14(1.7-398)}$ & $\frac{371 \pm 235}{435(46.8-568)}$ & $\frac{66 \pm 84}{20(14.5-163)}$ & $\frac{8 \pm 3}{6(5.5-11)}$ & $\frac{41 \pm 50}{25(4-109)}$ & $\frac{31 \pm 37}{12(7-74)}$ & $\frac{216 \pm 285}{216(14-418)}$ & 2.09 & 10 \\
\hline $\mathrm{Fe}$ & $\frac{438 \pm 891}{127(32-3339)}$ & $\frac{2684 \pm 2453}{2137(211-6051)}$ & $\frac{233 \pm 167}{171(111-478)}$ & $\frac{418 \pm 54}{414(359-483)}$ & $\frac{36 \pm 7}{39(27-42)}$ & $\frac{45 \pm 13}{50(32-59)}$ & $\frac{2010 \pm 1557}{1996(560-3488)}$ & 47.26 & 100 \\
\hline
\end{tabular}

Numerator-mean value \pm standard deviation; the denominator is the median (the minimum and maximum values of the sample); $n-$ number of samples. 


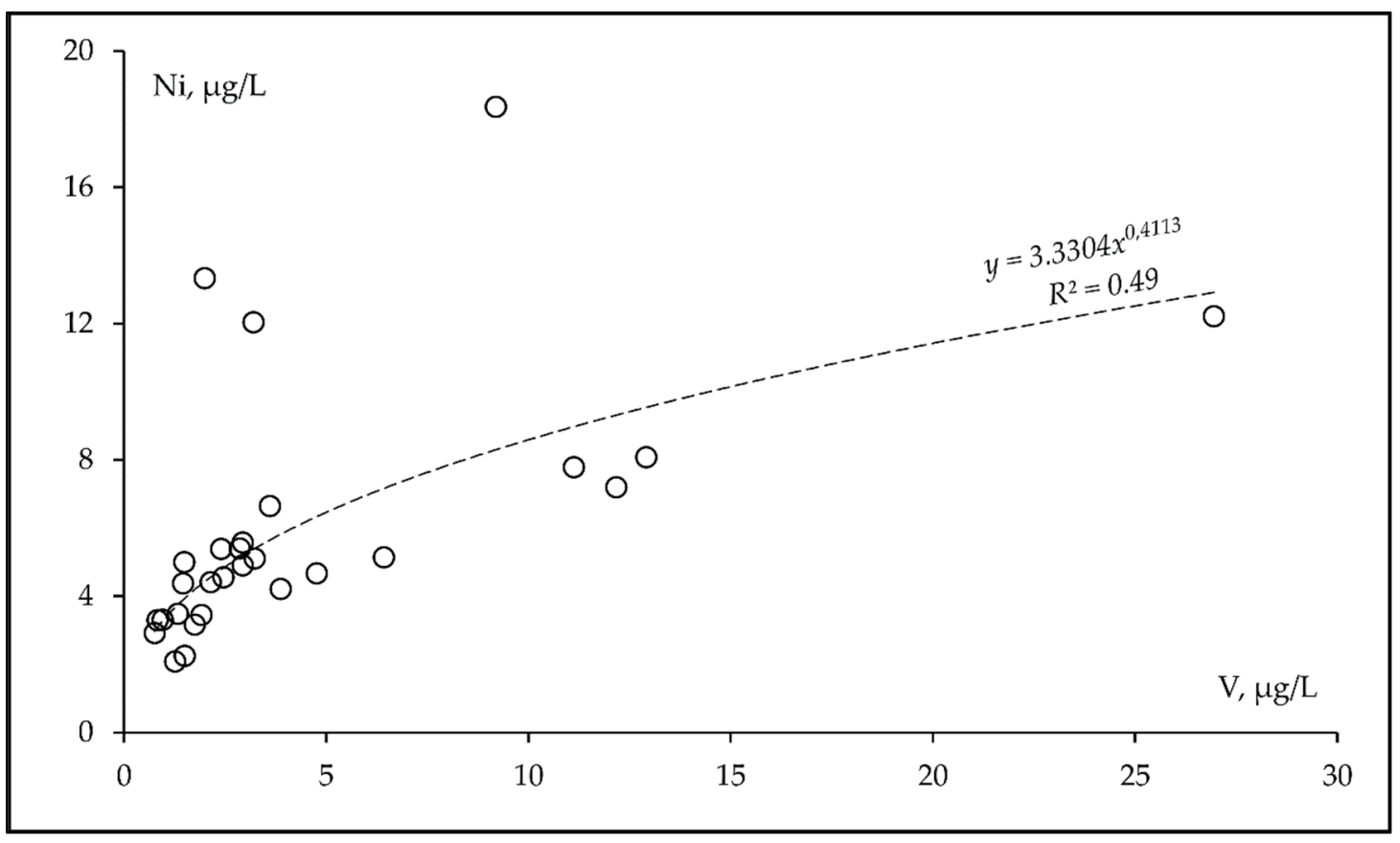

Figure 2. Correlation between Ni concentration and V content in the studied lakes.

Chromium and cobalt concentrations varied from 0.40 to $1.64 \mu \mathrm{g} / \mathrm{L}$ and from 0.1 to $1.39 \mu \mathrm{g} / \mathrm{L}$, respectively. The maximum concentrations of these elements (three times above the background) were found in Lake Ledovoe. Exceeding the maximum permissible concentrations for fishing has not been recorded.

The high content of copper in chemical composition of surface waters is a special feature of water bodies in the Arctic zone and the Russian North due to predominance of chalcophile elements in the Baltic Shield and humification of the catchment area of the lakes in Murmansk region [27]. The concentrations of $\mathrm{Cu}$ in Murmansk lakes varied from 1.33 to $2.62 \mu \mathrm{g} / \mathrm{L}$. The maximum content was found in Lake Ledovoe, the minimum in Lake Yuzhnoe. The majority of lakes were characterized by $\mathrm{Cu}$ concentrations higher than the background of the region and 0.7-1.6 times higher than the maximum permissible concentrations for fisheries.

During the research of the Murmansk lakes, zinc content varied from 1.64 to $17.22 \mu \mathrm{g} / \mathrm{L}$. Almost all the studied lakes were characterized by the exceeding the maximum permissible concentrations for this element. The exception is Lake Yuzhnoe with the lowest $\mathrm{Zn}$ concentration. $\mathrm{Zn}$ concentrations in Lake Severnoe and Lake Okunevoe were 1.5 and 1.7 times higher than the maximum permissible concentrations. Possibly, the high content of $\mathrm{Zn}$ in these lakes is connected with the deposition of plant residues in the catchment areas and further $\mathrm{Zn}$ transport with the surface run-off and from the soil horizon to the lakes in autumn and spring seasons [31,32]. The anthropogenic source of $\mathrm{Zn}$ input to the urban water bodies is dust from the highways. The enrichment of the road dust with $\mathrm{Zn}$ occurs due to tire abrasion and worn brake shoes [26,33].

Tungsten concentration in the lakes did not exceed the background. The exception is Lake Ledovoe with the $\mathrm{W}$ concentration of $1.4 \mu \mathrm{g} / \mathrm{L}$, that is $0.8 \mu \mathrm{g} / \mathrm{L}$ more than the background. W compounds are used in mechanical engineering for lubricants and polyamide composites as antifriction nanoparticles, that reduce the friction coefficient, and as catalysts for oil refining [34]. The gas station, the car wash, and garages are located near Lake Ledovoe, which is possibly a reason for the increase of $\mathrm{W}$ in this lake.

The Murmansk lakes are characterized by the relatively high content of $\mathrm{Fe}$, the exceptions are Lake Srednee and Lake Yuzhnoe, where the lowest concentrations of this element 
(36 and $47 \mu \mathrm{g} / \mathrm{L}$, respectively) were found. The maximum rates were observed in Lake Ledovoe $(2684 \mu \mathrm{g} / \mathrm{L})$ and Lake Treugolnoe $(2010 \mu \mathrm{g} / \mathrm{L}), 27$ and 20 times higher than the maximum permissible concentrations for fisheries. The main source of Fe in waters is rocks, where Fe exists in the bivalent form. During silicate weathering under the influence of carbonic acid and water, bivalent iron in the form of bicarbonates transports into waters. Under the influence of oxygen, bivalent iron further switches to trivalent, which breaks down hydrolytically to Iron (III) oxide-hydroxide in acid solutions [35]. Moreover, Fe has the capacity to complexation, creating stable complex compounds with humic substances (the main part of Fe exists in the complex anionic form) [36].

Manganese is a widespread element in the environment. Its mean content in the Murmansk lakes varied from 8 to $371 \mu \mathrm{g} / \mathrm{L}$. The highest concentrations compared to the background were found in Lake Ledovoe $(371 \mu \mathrm{g} / \mathrm{L})$ and Lake Treugolnoe $(215.85 \mu \mathrm{g} / \mathrm{L})$. The minimum Mn concentration was observed in Lake Okunevoe- $8 \mu \mathrm{g} / \mathrm{L}$. The Republic of Karelia and Murmansk region belong to the ferromanganese geochemical province, which causes migration of elements as part of organic-mineral complexes to the water bodies of these regions [37]. The strong correlation (Figure 3) between Fe and Mn contents in the studied lakes indicated simultaneous input of these elements. Moreover, the subarctic areas are characterized by eutrophication of lakes with the high content of humus [38]. As a result of low temperature influence and decrease in the oxygen content at the bottom of water bodies, Mn switches to the dissolved form (Mn(II)) and releases from sediments [39]. Anthropogenic sources of Mn are exhaust fumes of cars with gasoline engines, where methylcyclopentadienyl manganese tricarbonyl is used as an antiknock agent, and manganese antismoke agents for diesel fuel [40].

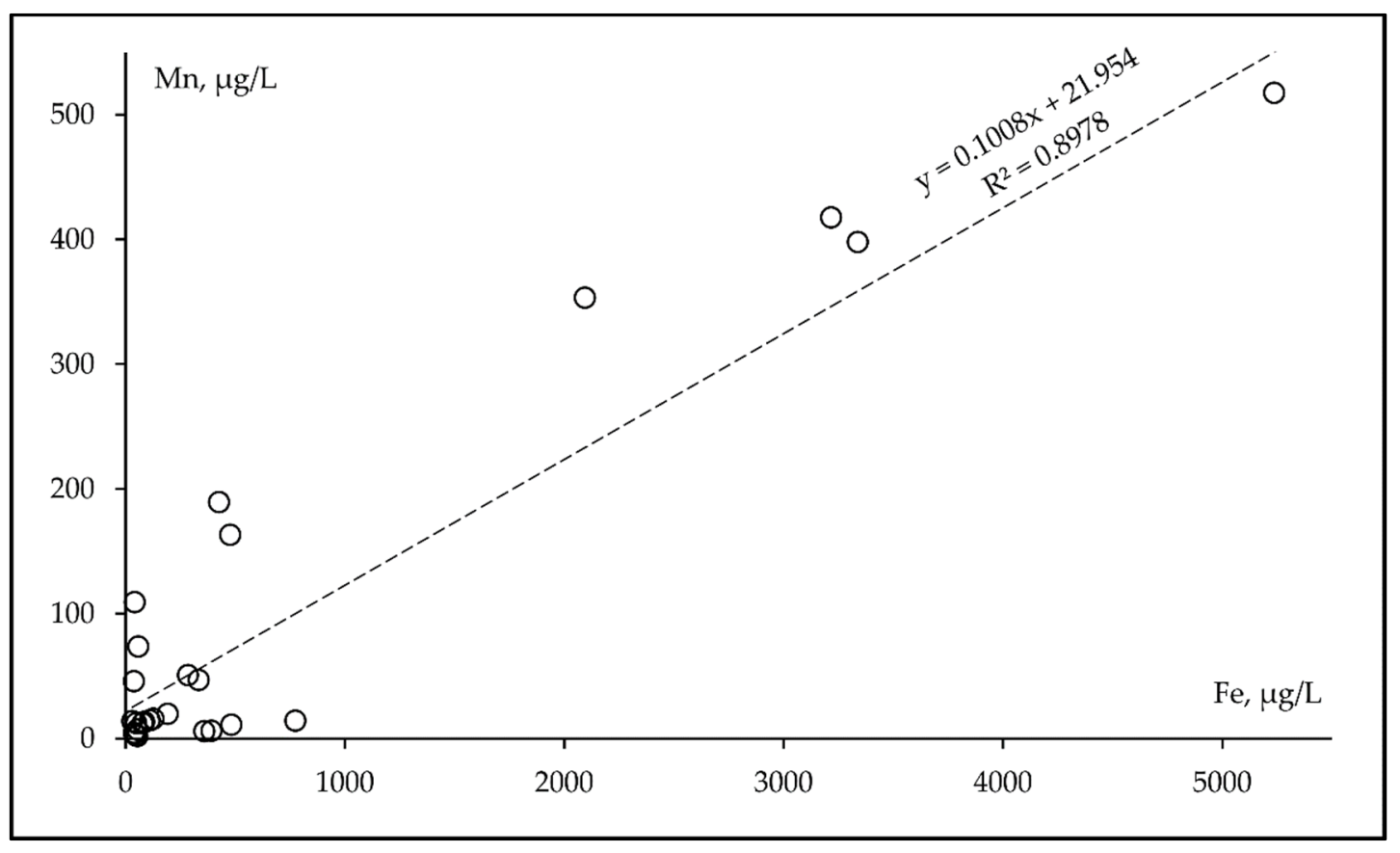

Figure 3. Correlation between Fe concentration and Mn content in the studied lakes.

Comparison of the concentrations of trace elements in the Murmansk lakes with their concentrations in the lakes of the border zones of Russia, Finland, and Norway (Table 3) showed that the concentration of $\mathrm{Cu}$ in the Murmansk lakes was on the same level as Norway. Moreover, Ni concentrations in the Murmansk lakes were 1.8 times higher than in Norway. The highest concentrations of these elements are common for the north-western part of Murmansk region. As noted above, $\mathrm{Cu}$ and $\mathrm{Ni}$ are some of the most common pollutants from non-ferrous metallurgical plants, located in this area. The highest concentrations were found in lakes located close to metallurgical plants: Lake 
Haukilampi (Cu-8.3 $\mu \mathrm{g} / \mathrm{L} ; \mathrm{Ni}-109 \mu \mathrm{g} / \mathrm{L}), \mathrm{LN}-2(\mathrm{Cu}-9.8 \mu \mathrm{g} / \mathrm{L} ; \mathrm{Ni}-265 \mu \mathrm{g} / \mathrm{L}), \mathrm{LN}-3$ $(\mathrm{Cu}-13.6 \mu \mathrm{g} / \mathrm{L} ; \mathrm{Ni}-111 \mu \mathrm{g} / \mathrm{L})$, Lake Kuetsjarvi $(\mathrm{Cu}-8.6 \mu \mathrm{g} / \mathrm{L} ; \mathrm{Ni}-106 \mu \mathrm{g} / \mathrm{L})$ [41]. The lowest concentrations of $\mathrm{Cu}, \mathrm{Ni}$, and $\mathrm{Pb}$ were observed in the lakes of Finland. The mean $\mathrm{Pb}$ content in other regions was similar and varied from 0.23 to $0.28 \mu \mathrm{g} / \mathrm{L}$. In turn, the lakes of Murmansk and Finland were characterized by high concentrations of the mean Fe content, which is common for small lakes in these regions. Meanwhile, the highest concentrations of Fe were observed in the Murmansk lakes and they were 1.9 times higher than in the Finnish lakes.

Table 3. The mean contents of microelements in the Murmansk lakes and the neighboring zones of Russia, Norway, and Finland, $\mu \mathrm{g} / \mathrm{L}$ [41].

\begin{tabular}{ccccc}
\hline & $\mathbf{C u}$ & $\mathbf{N i}$ & $\mathbf{P b}$ & $\mathbf{F e}$ \\
\hline Murmansk & 2.1 & 6.3 & 0.23 & 837 \\
\hline Russia & 5.2 & 41.6 & 0.26 & 98 \\
\hline Norway & 2.1 & 3.6 & 0.28 & 54 \\
\hline Finland & 0.9 & 1.5 & 0.09 & 434 \\
\hline
\end{tabular}

\subsection{Seasonal Variation}

The seasonal variation of the content of microelements in the Murmansk lakes was studied in Lake Semenovskoe due to its location in the central part of the city and its high recreational meaning for citizens.

The mean concentrations higher than the regional background were found in Lake Semenovskoe for these elements: $\mathrm{Cu}$ (1.8 times higher), Ni (3.9), Zn (3.9), V (4.2), Fe (9.3), and $\mathrm{Mn}$ (37). The highest concentrations were observed mainly in winter/spring season and reached their maximum in the flood period. Thus, there were high concentrations of $\mathrm{V}$ $(3.87 \mu \mathrm{g} / \mathrm{L}$ in winter; $6.42 \mu \mathrm{g} / \mathrm{L}$ in spring) and $\mathrm{Zn}(8.22 \mu \mathrm{g} / \mathrm{L}$ in winter; $15 \mu \mathrm{g} / \mathrm{L}$ in spring) in the surface water (Figures 4 and 5).

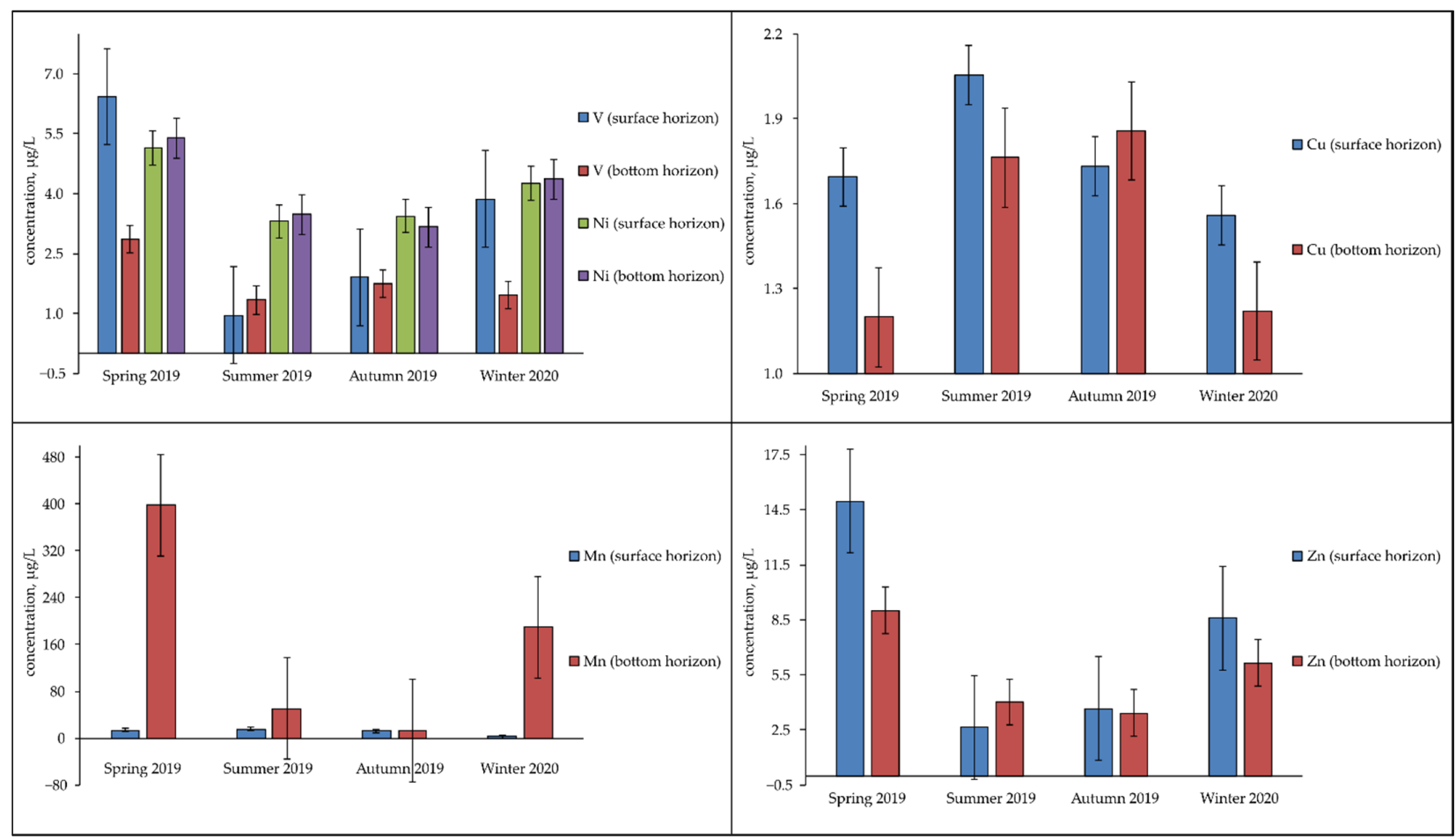

Figure 4. Seasonal and vertical variation of V, Ni, Mn, Cu, Zn contents in Lake Semenovskoe in 2019-2020. 


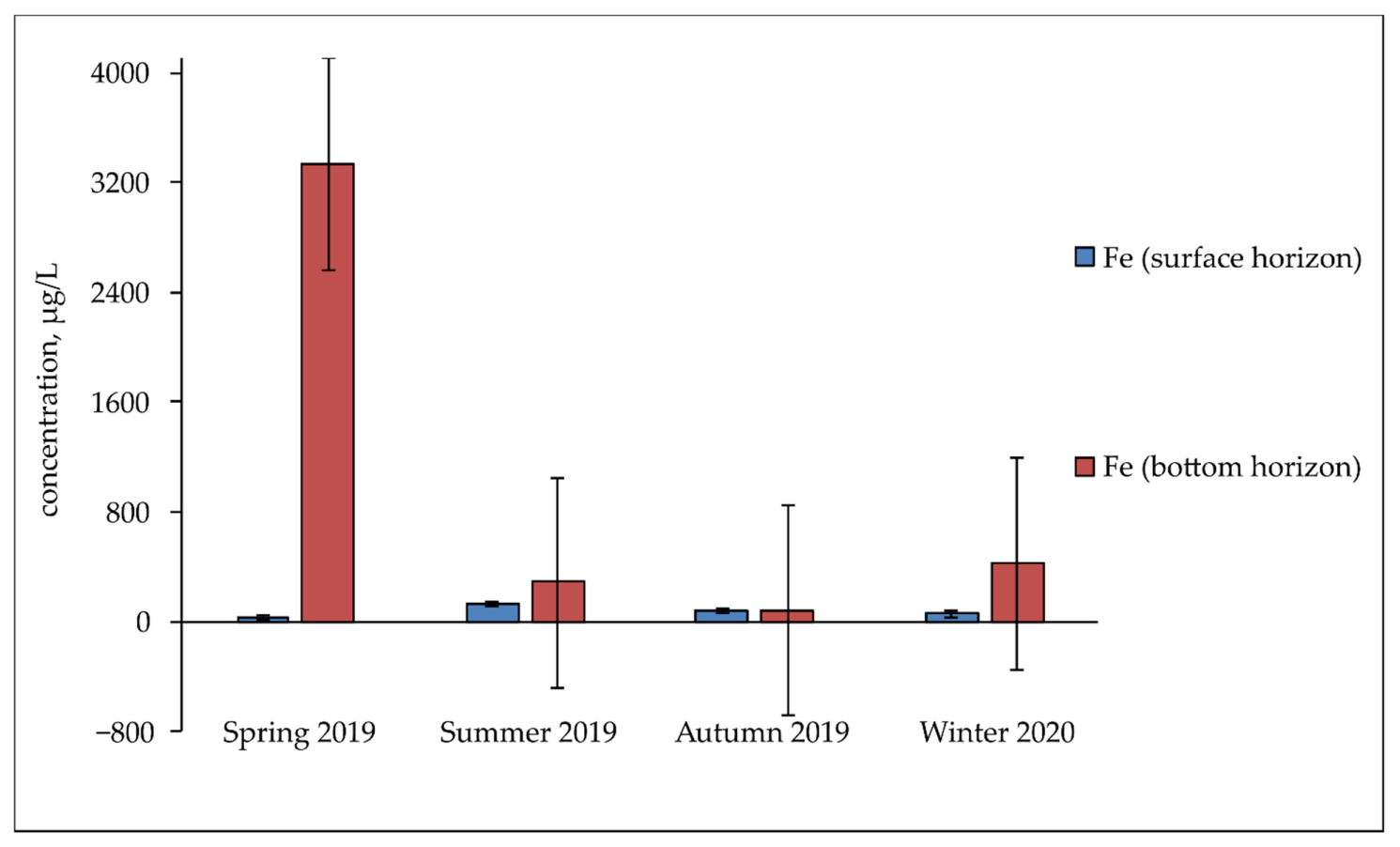

Figure 5. Seasonal and vertical variation of Fe content in Lake Semenovskoe in 2019-2020.

The highest contents of Mn were noted in the bottom water layer $(189 \mu \mathrm{g} / \mathrm{L}$ in winter; $398 \mu \mathrm{g} / \mathrm{L}$ in spring) and $\mathrm{Fe}(427 \mu \mathrm{g} / \mathrm{L} ; 3339 \mu \mathrm{g} / \mathrm{L}$ in spring). Iron and manganese cycling is common for natural water bodies [42]. During winter stagnation, active diffusion of $\mathrm{Fe}^{2+}$ and $\mathrm{Mn}^{2+}$ from sediments to water occurs and that leads to the accumulation of these elements in the bottom water. In summer, a significant decrease in concentrations of studied elements occurs compared to the spring season. For instance, $\mathrm{Zn}$ concentration was $12.4 \mu \mathrm{g} / \mathrm{L}$ less in the surface water and $4.98 \mu \mathrm{g} / \mathrm{L}$ less in the bottom water. Mn content in the surface water was on the same level in summer, while the concentration of this element in the bottom water was 7.8 times less compared to spring. A sharp decline in concentrations in summer in the bottom water is common also for Fe (content was 11.7 times less). In summer, when oxygen conditions improve, $\mathrm{Fe}^{2+}$ oxidation to hydroxides and $\mathrm{Mn}^{2+}$ oxidation to dioxide occurs, and concentrations of these elements in water bodies decrease. In autumn during homothermia, water masses mixing leads to equal distribution of elements in the water column of the lake. Thus, $\mathrm{Zn}$ content in the surface water was $3.67 \mu \mathrm{g} / \mathrm{L}$ and in the bottom water $3.41 \mu \mathrm{g} / \mathrm{L}$. The seasonal pattern of $\mathrm{Cu}$ proceeds without strong variations. The highest content of this element was observed in summer $(2.05 \mu \mathrm{g} / \mathrm{L}$ in the surface water; $1.76 \mu \mathrm{g} / \mathrm{L}$ in the bottom water) and spring $(1.73 \mu \mathrm{g} / \mathrm{L}$ in the surface water; $1.86 \mu \mathrm{g} / \mathrm{L}$ in the bottom water). In winter/spring season, the highest concentration of $\mathrm{Cu}$ was found in the surface water $(1.6 \mu \mathrm{g} / \mathrm{L})$. Meanwhile, the difference between $\mathrm{Ni}$ content in the surface and bottom water was not observed during the research.

\subsection{Assessment of the Level of Pollution of Water Bodies}

To assess the level of pollution of lake waters in Murmansk, a regional water pollution index (WPI ${ }_{\text {reg }}$ ) was calculated [36]. To calculate this indicator, only priority chemical indicators reflecting this type of pollution are used. This takes into account not only the toxicity of the elements in accordance with their maximum permissible concentrations for fishery reservoirs but also the geochemical background for uncontaminated reservoirs. The index takes into account not only the toxicity of elements from the maximum permissible concentrations for fisheries but also the geochemical background for unpolluted water bodies. WPIreg is calculated according to the formula: 


$$
\mathrm{WPI}_{\text {reg }}=\frac{1}{n} \sum \frac{C i}{R M P C} i^{\prime}
$$

where $\mathrm{C} i$-the actual concentration of the element in the water body; $\mathrm{RMPC} i$-the regional maximum permissible concentrations of the same element. Only the compounds with $C i \geq$ RMPC are used for the calculation, others, as well as substances reflecting the regional specifics of waters, are not taken into account. RMPC for substances with MPC > Cbackground ( $\mathrm{V}, \mathrm{Cr}, \mathrm{Co}, \mathrm{Ni}, \mathrm{Zn})$ are calculated as the geometric mean:

$$
\mathrm{RMPC}=\sqrt{\text { Cbackground } \times \text { MPC }}
$$

The sum

$$
\text { RMPC }=\text { Cbackground }+ \text { MPC }
$$

was used for elements with the background concentration on the same level as MPC $(\mathrm{Cu}$, $\mathrm{W})$. The regional water pollution indices, confirming the influence of anthropogenic load on the state and quality of Murmansk lakes, are presented in Table 4.

Table 4. The regional water pollution index $\left(\mathrm{WPI}_{\mathrm{reg}}\right)$ of the Murmansk lakes.

\begin{tabular}{ccc}
\hline Lake & WPI $_{\text {reg }}$ & Classification by WPI $_{\text {reg }}$ \\
\hline Semenovskoe & 2.1 & Polluted \\
\hline Ledovoe & 3.7 & Heavily polluted \\
\hline Severnoe & 2.5 & Polluted \\
\hline Okunevoe & 3.6 & Heavily polluted \\
\hline Srednee & 3.7 & Heavily polluted \\
\hline Yuzhnoe & 1.1 & Moderately polluted \\
\hline Treugolnoe & 2 & Polluted \\
\hline
\end{tabular}

As can be seen from Table 4, although the studied lakes are not directly exposed to wastewater discharge from the enterprises of Murmansk, WPI $\mathrm{I}_{\text {reg }}$ reflects the influence of the urban environment on the state of water bodies. At the same time, Lake Imandra (the largest water body in Murmansk region) is influenced by the multifactorial anthropogenic load from mining and metallurgical industries, iron ore production, energy complex, household wastewater, and characterized by the value of WPI $\mathrm{I}_{\text {reg }}$ from 0.9 to 2.5 . These values are close to those for the lakes of Murmansk [43]. On the other hand, the Syuskuyanjoki River (the Republic of Karelia, Russia), characterized by the low development of the catchment area

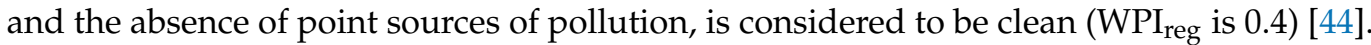
Additionally, WPI $\mathrm{I}_{\text {reg }}$ was calculated for the water of Lake Peipus ( $45 \%$ of the lake area belongs to Russia, 55\% to Estonia). This lake is exposed to the anthropogenic load from point (urban wastewater) and scattered (agricultural facilities) sources of pollution. WPI $\mathrm{I}_{\text {reg }}$ for this lake was 0.77 , which corresponds to the category of clean waters [45].

\section{Conclusions}

The results of the studies showed the significant influence of the urban environment on the chemical composition of the Murmansk lakes. The most polluted lake was Lake Ledovoe with the highest concentrations of $\mathrm{V}, \mathrm{Cr}, \mathrm{Co}, \mathrm{Ni}, \mathrm{Cu}, \mathrm{W}$, and $\mathrm{Mn}$. The least subject to anthropogenic load was Lake Yuzhnoe, characterized by the lowest concentrations of studied heavy metals. The highest excess of the background in the Murmansk lakes were found for $\mathrm{V}, \mathrm{Ni}, \mathrm{Zn}, \mathrm{Fe}$, and $\mathrm{Mn}$. The main reason for the high content of $\mathrm{V}$ and $\mathrm{Ni}$ is the combustion of mazut fuel. $\mathrm{Zn}$ and $\mathrm{Mn}$ concentrations can increase due to both natural and anthropogenic factors, influencing different processes in the surface and bottom waters. The analysis of the seasonal variation showed that the highest concentrations of heavy metals were observed in winter/spring season and reached their maximum during the 
period of melt water intake from the catchment area. The assessment of the quality of the Murmansk lakes using the regional water pollution index showed that Ledovoe, Okunevoe, and Srednee lakes can be characterized as "heavily polluted". Semenovskoe, Severnoe, and Treugolnoe lakes are "polluted". Only Lake Yuzhnoe is "moderately polluted".

Author Contributions: Conceptualization, M.A.P., V.A.D. and Z.I.S.; methodology, M.A.P. and D.S.B.; software, M.A.P.; validation, V.A.D. and Z.I.S.; investigation and resources, Z.I.S., V.A.D., M.A.P. and D.S.B.; data curation, Z.I.S.; writing-original draft preparation, M.A.P.; writing-review and editing, Z.I.S. and V.A.D.; visualization, M.A.P. and Z.I.S.; supervision, V.A.D.; project administration and funding acquisition, Z.I.S. All authors have read and agreed to the published version of the manuscript.

Funding: The research is supported by the Grant of the Russian Science Foundation, project No. 19-77-10007 (the seasonal dynamics of heavy metal pollution), the Grant from the Government of Murmansk region № 224 (the environmental assessment of the condition of urban lakes), and the State order of laboratory of geoecology and environmental management of the Arctic of INEP KSC RAS No. 1021111018324-1 (comparing pollutant concentrations with the background).

Acknowledgments: The authors sincerely thank the colleagues from Apatity: D.B. Denisov and A.A. Cherepanov for the help with sampling, A.A. Cherepanov for creating the study area map, and I.R. Elizarova for the high-quality analytical studies. Additionally, the authors sincerely thank D.A. Tikhonova for translating the article to English.

Conflicts of Interest: The authors declare no conflict of interest.

\section{References}

1. Venäläinen, E.R. The Levels of Heavy Metals in Moose, Reindeer and Hares in Finlandresults of Twenty Years' Monitoring. Ph.D. Thesis, University of Kuopio, Kuopio, Finland, 2007.

2. Klavins, M.; Potapovics, O.; Rodinov, V. Heavy Metals in Fish from Lakes in Latvia: Concentrations and Trends of Changes. Bull. Environ. Contam. Toxicol. 2008, 82, 96-100. [CrossRef] [PubMed]

3. Moiseenko, T.I.; Gashkina, N.A. Distribution and bioaccumulation of heavy metals $(\mathrm{Hg}, \mathrm{Cd}$ and $\mathrm{Pb})$ in fish: Influence of the aquatic environment and climate. Environ. Res. Lett. 2020, 15, 115013. [CrossRef]

4. Kutsenko, S.A. Fundamentals of Toxicology; Foliant: Moscow, Russia, 2004; 570p. (In Russian)

5. Trautmann, S.; Wolfe, B.A.; Jorgensen, P.; Tyers, M.; Gould, K.L.; McCollum, D. Fission yeast Clp1p phosphatase regulates G2/M transition and coordination of cytokinesis with cell cycle progression. Curr. Biol. 2001, 11, 931-940. [CrossRef]

6. Amundsen, P.-A.; Kashulin, N.A.; Terentjev, P.; Gjelland, K.; Koroleva, I.M.; Dauvalter, V.A.; Sandimirov, S.; Kashulin, A.; Knudsen, R. Heavy metal contents in whitefish (Coregonus lavaretus) along a pollution gradient in a subarctic watercourse. Environ. Monit. Assess. 2011, 182, 301-316. [CrossRef] [PubMed]

7. Shilova, N.A. Influence of Heavy Metals on Representatives of Freshwater Phyto- and Zooplankton under Conditions of Salinity. Ph.D. Thesis, Saratov State University Named after N.G. Chernyshevsky, Saratov, Russia, 2014. (In Russian)

8. Bradl, H.B. Chapter 1 Source and Origins of Heavy Metals. In Heavy Metals in the Environment: Origin, Interaction and Remediation, 1st ed.; Bradl, H.B., Ed.; Elsevier: Amsterdam, The Netherlands, 2005; pp. 1-27. [CrossRef]

9. Kashulin, N.A.; Dauvalter, V.A.; Denisov, D.B.; Valkova, S.A.; Vandysh, O.I.; Terentjev, P.M.; Kashulin, A.N. Selected aspects of the current state of freshwater resources in the Murmansk Region, Russia. J. Environ. Sci. Health Part A 2017, 52, 921-929. [CrossRef] [PubMed]

10. Golovanova, O.A.; Malovskaya, E.A. Dynamics of pollution by ions of heavy metals of surface waters of the rivers of the Siberian region. Bull. Omsk. Univ. 2016, 3, 64-73. (In Russian)

11. Masindi, V.; Muedi, K.L. Environmental Contamination by Heavy Metals. In Heavy Metals; Intech Open: London, Great Britain, 2018; pp. 115-133. [CrossRef]

12. Osipova, L.A.; Kargin, S.A.; Ilyazova, F.S.; Veremeenko, O.V. Pollution of the waters of the Volga-Caspian basin with salts of heavy metals. Bull. ASTU 2008, 3, 126-131. (In Russian)

13. Xia, W.; Wang, R.; Zhu, B.; Rudstam, L.G.; Liu, Y.; Xu, Y.; Xin, W.; Chen, Y. Heavy metal gradients from rural to urban lakes in central China. Ecol. Process. 2020, 9, 47. [CrossRef]

14. Johnson, A.W.; Gutiérrez, M.; Gouzie, D.; McAliley, L.R. State of remediation and metal toxicity in the Tri-State Mining District, USA. Chemosphere 2016, 144, 1132-1141. [CrossRef]

15. Rentz, R.; Öhlander, B. Urban impact on water bodies in the Luleå area, northern Sweden, and the role of redox processes. Hydrol. Res. 2012, 43, 917-932. [CrossRef]

16. Dauvalter, V.; Moiseenko, T.; Kudryavtseva, L.; Sandimirov, S. Accumulation of heavy metals in Lake Imandra because of its pollution with industrial waste. Water Resour. 2000, 27, 279-287. 
17. Dauvalter, V.A.; Kashulin, N.A. Mercury Pollution of Lake Imandra Sediments, the Murmansk Region, Russia. Int. J. Environ. Res. 2018, 12, 939-953. [CrossRef]

18. Alekin, O.A. Fundamentals of Hydrochemistry; Hydrometeoizdat: Leningrad, Russia, 1970; 444p. (In Russian)

19. Moiseenko, T.I.; Gashkina, N. Zonal features of lake acidification. Water Resour. 2011, 38, 47-62. [CrossRef]

20. Slukovskii, Z.; Dauvalter, V.; Guzeva, A.; Denisov, D.; Cherepanov, A.; Siroezhko, E. The Hydrochemistry and Recent Sediment Geochemistry of Small Lakes of Murmansk, Arctic Zone of Russia. Water 2020, 12, 1130. [CrossRef]

21. Clescerl, L.S.; Greenberg, A.E.; Eaton, A.D. Standard Methods for Examination for Water and Wastewater, 20th ed.; American Public Health Association USA: Washington, DC, USA, 1999; 2671p.

22. Bazova, M.M. Specifics of the elemental composition of waters in environments with operating mining and ore-processing plants in the Kola North. Geochem. Int. 2017, 55, 131-143. [CrossRef]

23. List of Fishery Standards: Maximum Permissible Concentrations (MPC) and Tentatively Safe Exposure Levels (TSEL) of Harmful Substances for Water of Water Bodies with A Fishery Purpose; VNIRO: Moscow, Russia, 2016; 134p. (In Russian)

24. Ganor, E.; Altshuller, S.; Foner, H.A.; Brenner, S.; Gabbay, J. Vanadium and nickel in dustfall as indicators of power plant pollution. Water Air Soil Pollut. 1988, 42, 241-252. [CrossRef]

25. Hernandez, H.; Rodriguez, R. Geochemical evidence for the origin of vanadium in an urban environment. Environ. Monit. Assess. 2011, 184, 5327-5342. [CrossRef] [PubMed]

26. Sayet, Y.E.; Revich, B.A.; Yanin, E.P.; Smirnova, R.S.; Basharkevich, I.L.; Onishchenko, T.L.; Pavlova, L.N.; Trefilova, N.Y.; Achkasov, A.I.; Sarkisyan, S.S. Geochemistry of the Environment; Nedra: Moscow, Russia, 1990; 335p. (In Russian)

27. Yanin, E.P.; Kuzmich, V.N.; Ivanitskiy, O.M. Regional natural heterogeneity of the chemical composition of land surface waters and the need to take it into account when assessing their ecological state and the intensity of technogenic pollution. Probl. Environ. Nat. Resour. 2016, 6, 3-72. (In Russian)

28. Zoller, W.H.; Gordon, G.E.; Gladney, E.S.; Jones, A.G. The Sources and Distribution of Vanadium in the Atmosphere. In Trace Elements in the Environment; American Chemical Society: Washington, DC, USA, 1975; Chapter 3; pp. 31-47. [CrossRef]

29. Agrawal, H.; Malloy, Q.G.; Welch, W.A.; Miller, J.W.; Cocker, D.R. In-use gaseous and particulate matter emissions from a modern ocean going container vessel. Atmos. Environ. 2008, 42, 5504-5510. [CrossRef]

30. Peltier, R.E.; Lippmann, M. Residual oil combustion: 2. Distributions of airborne nickel and vanadium within New York City. J. Expo. Sci. Environ. Epidemiol. 2009, 20, 342-350. [CrossRef] [PubMed]

31. Kabata-Pendias, A.; Pendias, H. Trace Elements in Soils and Plants; Mir: Moscow, Russia, 1989; 439p. (In Russian)

32. Titov, A.F.; Kaznina, N.M.; Talanova, V.V. Heavy Metals and Plants; Karelian Scientific Center of the Russian Academy of Sciences: Petrozavodsk, Russia, 2014; 194p. (In Russian)

33. Hwang, H.-M.; Fiala, M.; Park, D.; Wade, T.L. Review of pollutants in urban road dust and stormwater runoff: Part 1. Heavy metals released from vehicles. Int. J. Urban Sci. 2016, 20, 334-360. [CrossRef]

34. Privalenko, A.N.; Balak, G.M.; Bagramova, E.K.; Zueva, V.D.; Pulyaev, N.N. Atomic absorption determination of the content of metals in oil fuels. Int. Tech. Econ. J. 2013, 5, 97-108. (In Russian)

35. Romanovskaya, S.L. Study of The Influence of a Number of Natural and Anthropogenic Factors on The Chemical Composition of a Water Source and Drinking Water. Ph.D. Thesis, Ufa State Petroleum Technical University, Ufa, Russia, 2005. (In Russian)

36. Lozovik, P.A.; Efremova, N.A.; Ryzhakov, A.V.; Borodulina, G.S.; Sabylina, A.V.; Zobkov, M.B.; Zaitsev, D.O.; Basova, S.V.; Kalmykov, M.V.; Perskaya, E.A.; et al. Analytical, Kinetic and Computational Methods in Hydrochemical Practice; Nestor-History: St. Petersburg, Russia, 2017; 272p. (In Russian)

37. Belkina, N.A.; Subetto, D.A. Modern Sedimentogenesis of the Lakes of South Karelia. Geography: Development of Science and Education. In Proceedings of the Collective Monograph on Materials of the Scientific and Practical Conference LXXIII Gertsenovsky Readings, RSPU of A.I. Herzen, St. Petersburg, Russia, 22-25 April 2020; Volume 1, pp. 267-271. (In Russian)

38. Dauval'Ter, V.A.; Il'Yashuk, B.P. Conditions of formation of ferromanganese nodules in the bottom sediments of lakes in the Baltic shield. Geochem. Int. 2007, 45, 615-619. [CrossRef]

39. Gorlenko, V.M.; Dubinina, G.A.; Kuznetsov, S.I. Ecology of Aquatic Microorganisms; Nauka: Moscow, Russia, 1977; 289p. (In Russian)

40. Shumilova, M.A.; Sadiullina, O.V.; Lebedeva, M.G.; Petrov, V.G. Distribution of manganese compounds as a pollutant of urban areas on the example of cities of the Urals. Bull. Udmurt Univ. Ser. Phys. Chem. 2013, 4, 33-38. (In Russian)

41. Kashulin, N.A.; Dauvalter, V.A.; Sandimirov, S.S.; Sandimirov, S.S.; Terentyev, P.M.; Koroleva, I.M. Catalogue of Lakes in the Russian, Finnish and Norwegian Border Area; Kopijyva Oy: Jyvaskyla, Finland, 2008; 313p.

42. Mortimer, C.H. The Exchange of Dissolved Substances between Mud and Water in Lakes. J. Ecol. 1942, 30, 147-201. [CrossRef]

43. Galakhina, N.E.; Lozovik, P.A. Assessment of Water Pollution and Rationing Permissible Anthropogenic Impact on them by Toxic Substances. In Proceedings of the Modern Problems of Quaternary Geology and Geography of the North-West of the European Part of Russia and Neighboring Countries: Materials of a Scientific Session (with the Participation of Foreign Specialists) Dedicated to the 100th Anniversary of the Birth of Galina Sergeevna Biske, Petrozavodsk, Russia, 9-10 March 2017; pp. 102-105. (In Russian)

44. Komulainen, S.F.; Lozovik, P.A.; Kruglova, A.N.; Baryshev, I.A.; Slastina, Y.L.; Galibina, N.A. The current state of the Syuskuyanjoki River (Lake Ladoga basin, Republic of Karelia). Proc. KarSC RAS 2017, 7, 19-33. (In Russian) [CrossRef]

45. Lozovik, P.A.; Frumin, G.T. The current state and permissible biogenic loads on the Pskov-Peipsi Lake. Proc. KarSC RAS 2018, 3, 3-10. (In Russian) 